\title{
The relationship of cardiovascular risk factors to the prevalence of coronary heart disease in newly diagnosed Type 2 (non-insulin-dependent) diabetes
}

\author{
M. Uusitupa ${ }^{1}$, Onni Siitonen ${ }^{1}$, K. Pyörälä ${ }^{1}$, A. Aro ${ }^{1}$, K. Hersio ${ }^{2}$, I.Penttilä ${ }^{2}$ and E. Voutilainen ${ }^{1}$ \\ Departments of ${ }^{1}$ Medicine and Clinical ${ }^{2}$ Chemistry, Kuopio University Central Hospital, Kuopio, Finland
}

Summary. The relationship of cardiovascular risk factors to the prevalence of coronary heart disease was examined in 133 newly diagnosed Type 2 (non-insulin-dependent) diabetic patients ( 70 men, 63 women) aged from 45 to 64 years and in 144 randomly selected non-diabetic control subjects $(62 \mathrm{men}$, 82 women) of the same age. The prevalence of coronary heart disease in diabetic patients, defined by symptoms and ischaemic ECG abnormalities in resting or exercise ECG, was more than threefold that in non-diabetic subjects. In multiple logistic analyses (including age, history of smoking, hypertension $(+/-)$, serum cholesterol, HDL-cholesterol, triglycerides, 2-h post-glucose serum insulin, body mass index and diabetes $(+/-))$ carried out separately for men and women, diabetes showed an independent, significant association to coronary heart disease in both sexes. In addition, age and hypertension had a borderline association to coronary heart disease in men, whereas smoking and high 2 -h postglucose serum insulin level showed a significant association in women.

Key words: Type 2 diabetes, coronary heart disease, cardiovascular risk factors, hyperinsulinaemia.
Coronary heart disease (CHD) is more common in the diabetic than in the non-diabetic population [1, 2]. Type 2 diabetes may be preceded by a long period of glucose intolerance $[3,4]$ and associated metabolic abnormalities which may promote the development of CHD. Although the significance of asymptomatic hyperglycaemia per se as a risk factor for CHD appears to be controversial [5] some prospective population studies have shown that subjects with impaired glucose tolerance have an increased risk of morbidity and mortality from CHD [6-9]. Compatible with that is the finding that various manifestations of CHD are more common in newly diagnosed middle-aged Type 2 diabetic patients than in corresponding non-diabetic subjects [10].

The purpose of the present study was to investigate factors associated with the increased prevalence of CHD in subjects with newly diagnosed Type 2 diabetes.

\section{Subjects and methods}

\section{Subjects}

The final diabetic population consisted of 133 newly diagnosed Type 2 diabetic patients ( 70 men, 63 women) aged 45 - 64 years who were referred to the study by general practitioners working in community health centres in the survey area. The diagnosis of diabetes was primarily made in the clinical setting [10] and it was confirmed by an oral glucose tolerance test using diagnostic criteria recommended by the WHO [11]. Subjects with secondary diabetes, thyroid diseases, alcoholism, renal insufficiency, overt carcinoma or those in institutional care were not eligible for the study. Altogether 11 diabetic subjects originally referred to the study were excluded. Five did not fulfil the diagnostic criteria of diabetes, one had hypothyroidism, three were outside the age limits and two failed to complete the study. All the diabetic patients were non-ketotic at the time of diagnosis and none needed insulin treatment during the follow-up period of at least 3 months. The non-diabetic control population of the same age group (62 men, 82 women) was selected randomly from the population registers of the study area using random number tables. Of 183 subjects originally contacted, one had hypothyroidism, nine had diabetes and 29 refused to participate in the study. The mean \pm SEM age for male diabetic subjects was $55 \pm 0.7$ years, for male control subjects $53 \pm$ 0.7 years $(p<0.001)$ and for female diabetic and control subjects $57 \pm 0.7$ years and $54 \pm 0.6$ years $(p<0.001)$, respectively. Details of the study population have been reported elsewhere [10].

Approval for the study was given by the Ethical Committee of the University of Kuopio. Informed consent was given by all subjects.

\section{Study design}

A medical history included history of cardiovascular and other significant diseases, use of drugs, history of smoking and physical activity during leisure time and at work. Chest pain symptoms suggestive of CHD were recorded by the questionnaire developed by Rose [12]. Conventional 12-lead ECGs were recorded and analyzed according to the Minnesota code [13]. An exercise ECG was performed in the sitting position on an electrically braked bicycle ergometer (Mingo- 
Table 1. Clinical characteristics of diabetic and non-diabetic subjects

\begin{tabular}{|c|c|c|c|c|}
\hline \multirow[t]{2}{*}{ Variable } & \multicolumn{2}{|l|}{ Men } & \multicolumn{2}{|l|}{ Women } \\
\hline & $\begin{array}{l}\begin{array}{l}\text { Diabetic } \\
\text { subjects }\end{array} \\
(n=70)\end{array}$ & $\begin{array}{l}\text { Non- } \\
\text { diabetic } \\
\text { subjects } \\
(n=62)\end{array}$ & $\begin{array}{l}\text { Diabetic } \\
\text { subjects } \\
(n=63)\end{array}$ & $\begin{array}{l}\text { Non- } \\
\text { diabetic } \\
\text { subjects } \\
(n=82)\end{array}$ \\
\hline $\begin{array}{l}\text { Body mass index } \\
\left(\mathrm{kg} / \mathrm{m}^{2}\right)\end{array}$ & $29.7 \pm 0.6^{\mathrm{b}}$ & $26.9 \pm 0.4$ & $31.3 \pm 0.7^{b}$ & $27.2 \pm 0.5$ \\
\hline $\begin{array}{l}\text { Fasting blood glu- } \\
\text { cose }(\mathrm{mmol} / \mathrm{l})\end{array}$ & $10.3 \pm 0.4$ & $5.1 \pm 0.1$ & $11.2 \pm 0.5$ & $4.8 \pm 0.1$ \\
\hline $\begin{array}{l}\text { 1-h blood glucose } \\
(\mathrm{mmol} / 1)\end{array}$ & $17.5 \pm 0.7$ & $7.3 \pm 0.3$ & $18.6 \pm 0.7$ & $6.4 \pm 0.2$ \\
\hline $\begin{array}{l}\text { 2-h blood glucose } \\
(\mathrm{mmol} / \mathrm{l})\end{array}$ & $16.4 \pm 0.7$ & $5.7 \pm 0.3$ & $18.6 \pm 0.7$ & $6.0 \pm 0.2$ \\
\hline $\begin{array}{l}\text { Fasting serum in- } \\
\text { sulin }(\mathrm{mU} / \mathrm{l})\end{array}$ & $24 \pm 2^{\mathrm{b}}$ & $16 \pm 1$ & $26 \pm 2^{b}$ & $15 \pm 1$ \\
\hline $\begin{array}{l}\text { 1-h serum insulin } \\
(\mathrm{mU} / 1)\end{array}$ & $59 \pm 5^{b}$ & $92 \pm 9$ & $71 \pm 7^{a}$ & $82 \pm 6$ \\
\hline $\begin{array}{l}\text { 2-h serum insulin } \\
(\mathrm{mU} / \mathrm{l})\end{array}$ & $59 \pm 6$ & $52 \pm 8$ & $72 \pm 7$ & $70 \pm 5$ \\
\hline $\begin{array}{l}\text { Serum cholesterol } \\
(\mathrm{mmol} / \mathrm{l})\end{array}$ & $6.3 \pm 0.2$ & $6.7 \pm 0.2$ & $6.5 \pm 0.2$ & $6.7 \pm 0.1$ \\
\hline $\begin{array}{l}\text { HDL-cholesterol } \\
(\mathrm{mmol} / \mathrm{l})\end{array}$ & $0.99 \pm 0.03^{\mathrm{b}}$ & $1.25 \pm 0.04$ & $1.17 \pm 0.04^{b}$ & $1.41 \pm 0.04$ \\
\hline $\begin{array}{l}\text { Serum triglycer- } \\
\text { ides }(\mathrm{mmol} / \mathrm{l})\end{array}$ & $2.49 \pm 0.35^{\mathrm{a}}$ & $1.90 \pm 0.20$ & $2.37 \pm 0.20^{b}$ & $1.38 \pm 0.07$ \\
\hline $\begin{array}{l}\text { Serum uric acid } \\
(\mu \mathrm{mol} / \mathrm{l})\end{array}$ & $313 \pm 10$ & $317 \pm 8$ & $289 \pm 13^{\mathrm{a}}$ & $247 \pm 7$ \\
\hline $\begin{array}{l}\text { Current smokers } \\
(\%)\end{array}$ & 24 & 18 & 9 & 6 \\
\hline Ex-smokers (\%) & 57 & 50 & 4 & 1 \\
\hline $\begin{array}{l}\text { Prevalence of hy- } \\
\text { pertension }{ }^{\mathrm{c}}(\%)\end{array}$ & 63 & 38 & 70 & 42 \\
\hline $\begin{array}{l}\text { Prevalence of } \\
\text { myocardial } \\
\text { infarction (\%) }\end{array}$ & 17 & $\begin{array}{c}0.005 \\
10\end{array}$ & $p=0$ & $\begin{array}{l}.002 \\
4 \\
007\end{array}$ \\
\hline $\begin{array}{l}\text { Prevalence of cor- } \\
\text { onary heart dis- } \\
\text { ease by symp- } \\
\text { toms and ECG } \\
(\%)\end{array}$ & 32 & 0.001 & $p=0$. & 14 \\
\hline
\end{tabular}

Results given as mean \pm SEM or age-adjusted prevalence $(\%)$.

a $p<0.05 ;$ b $p<0.001$ (two way analysis of variance with group and age as factors); ${ }^{c}$ systolic blood pressure $\geqslant 160 \mathrm{mmHg}$ and/or diastolic blood pressure $\geqslant 95 \mathrm{~mm} \mathrm{Hg}$ and/or drug treatment for hypertension

graph 81, Elema-Schönander, Solna, Sweden) starting at a work load of $50 \mathrm{~W}$. The work load was increased stepwise by $50 \mathrm{~W}$ at 4-min intervals. The exercise test was continued until $85 \%$ of the predicted maximum heart rate was attained or to the subjective maximum. An ST segment depression of $\geqslant 1 \mathrm{~mm} 0.08$ seconds after the end of QRScomplex during or after exercise was regarded as pathological.

The following criteria for CHD were used: (1) definite myocardial infarction, including subjects with major Q-QS abnormalities (Minnesota code 1.1-2) and/or myocardial infarction verified at hospital, (2) coronary heart disease by symptoms and ECG, including subjects with severe chest pain attack and/or angina pectoris and ischaemic ECG abnormalities in resting (Minnesota code 1.1-3, 4.1-3, 5.1-3, 7.1) or exercise ECG. Thus the two groups of CHD were not mutually exclusive.

In this study subjects were classified into two groups according to physical activity during leisure time and at work. A physically active group during leisure time practiced at least 1-2 times a week walking, jogging, swimming, bicycling or corresponding activity for at least 30 min. A physically inactive group consisted of subjects with no or only irregulàr physical activity. The physically active group at work included persons with moderate (e.g. salesman, laboratory assistant) or heavy (e.g. heavy industrial work, farming, lumberjacking) physical activity. The physically inactive group included persons working principally in the sitting position (e.g. office work, teaching).

Blood pressure was measured in the sitting position after a 5 -min rest with mercury sphygmomanometer (cuff size $12.5 \times 40 \mathrm{~cm}$ ). Systolic and diastolic blood pressures were read to the nearest $2 \mathrm{mmHg}$. The diagnosis of hypertension was based on the following criteria: systolic blood pressure $\geqslant 160 \mathrm{mmHg}$ or diastolic blood pressure $\geqslant 95 \mathrm{mmHg}$ or drug treatment for hypertension.

Body mass index was calculated according to the following formula: body mass index $=$ weight $(\mathrm{kg}) /$ height $^{2}(\mathrm{~m})$.

An oral glucose tolerance test was performed. Whole venous blood glucose and serum insulin samples were taken in the fasting condition and at 1 and $2 \mathrm{~h}$. Samples for serum insulin were taken into pre-chilled tubes, centrifuged and stored without delay at $-20^{\circ} \mathrm{C}$ until analysis. Blood glucose was determined by a glucose oxidase method (Glox Kabi, Stockholm, Sweden). Serum insulin was determined by a radioimmunoassay (antiserum M8309; Novo Copenhagen, Denmark). The sensitivity of the method was $2 \mathrm{mU} / 1$ and the coefficient of variation $5.4 \%$. In the fractionation of serum lipoproteins, VLDL was separated by ultracentrifugation at $d 1.006\left(105000 \mathrm{~g}, \mathrm{t}+10^{\circ} \mathrm{C}\right.$, $18 \mathrm{~h}$ ) and HDL was precipitated from bottom fraction by dextran sulphate and magnesium chloride [14]. Enzymatic methods were used for the determination of cholesterol [15] and triglycerides [16]. The interassay and intra-assay coefficient of variation for cholesterol were $1.3 \%$ and $3.3 \%$, respectively. The corresponding coefficients of variation for triglycerides were $3.1 \%$ and $5.2 \%$ and for HDL-cholesterol $1.0 \%$ and $1.9 \%$.

\section{Statistical methods}

Age adjustment was carried out by a direct standardization method using the Finnish male and female population in the age group of 45-64 years in 1980 as a standard population. The significance of differences between the adjusted rates were analysed by a test of proportions based on standardized normal distribution [17]. Chi-square test was used for statistical analyses of significance of differences between rates of myocardial infaretion and coronary heart disease by symptoms and ECG with respect to the presence or absence of hypertension and history of smoking. Analysis of variance (ANOVA) with group and age as factors was used in the statistical analyses of differences between groups concerning continuous variables. Analysis of covariance (ANCOVA) was used for controlling the effect of obesity (body mass index) on insulin levels. Multiple logistic analyses were used to assess the independent contribution of various CHD risk factors to the occurrence of CHD. Serum insulin and triglycerides were analysed after logarithmic transformation.

\section{Results}

\section{Baseline characteristics}

Baseline characteristics of the study population are shown in Table 1. On average, the diabetic patients were significantly more obese than the non-diabetic control subjects. Fasting serum insulin levels were higher in both sexes of diabetic subjects than in the corresponding non-diabetic subjects. In contrast, the mean 1-h post-glucose serum insulin level was lower in the diabetic subjects. No difference was found in 2-h post-glucose serum insulin level between the two groups. There was no significant difference in serum total cholesterol levels between diabetic and non-diabetic subjects, but the HDL-cholesterol level was lower in both male and female diabetic subjects than in the corresponding nondiabetic subjects $(p<0.001)$. Diabetic subjects showed higher levels of serum total triglycerides than non-diabetic subjects. Female diabetic subjects had higher se- 


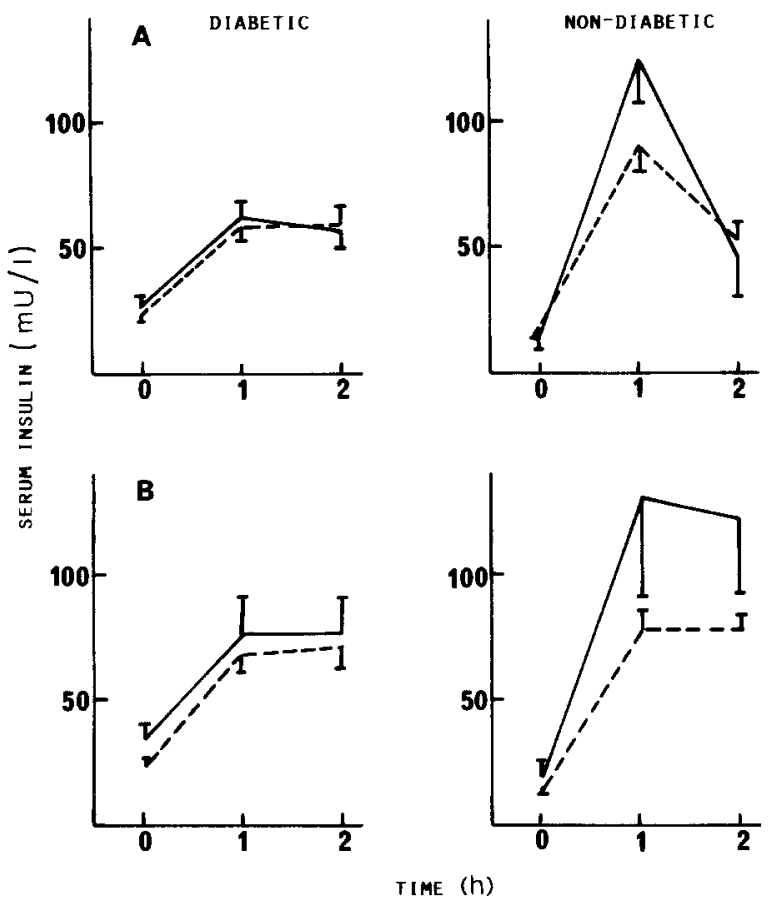

Fig. $1 \mathrm{~A}$ and B. Fasting and post-glucose serum insulin levels in relation to previous myocardial infarction in A men and $\mathbf{B}$ women. subjects with myocardial infarction ( $n=13$ for diabetic men, 5 for non-diabetic men, 11 for diabetic women and 4 for non-diabetic women), - - - subjects without myocardial infarction ( $n=57$ for diabetic men, 57 for non-diabetic men, 52 for diabetic women and 78 for non-diabetic women)

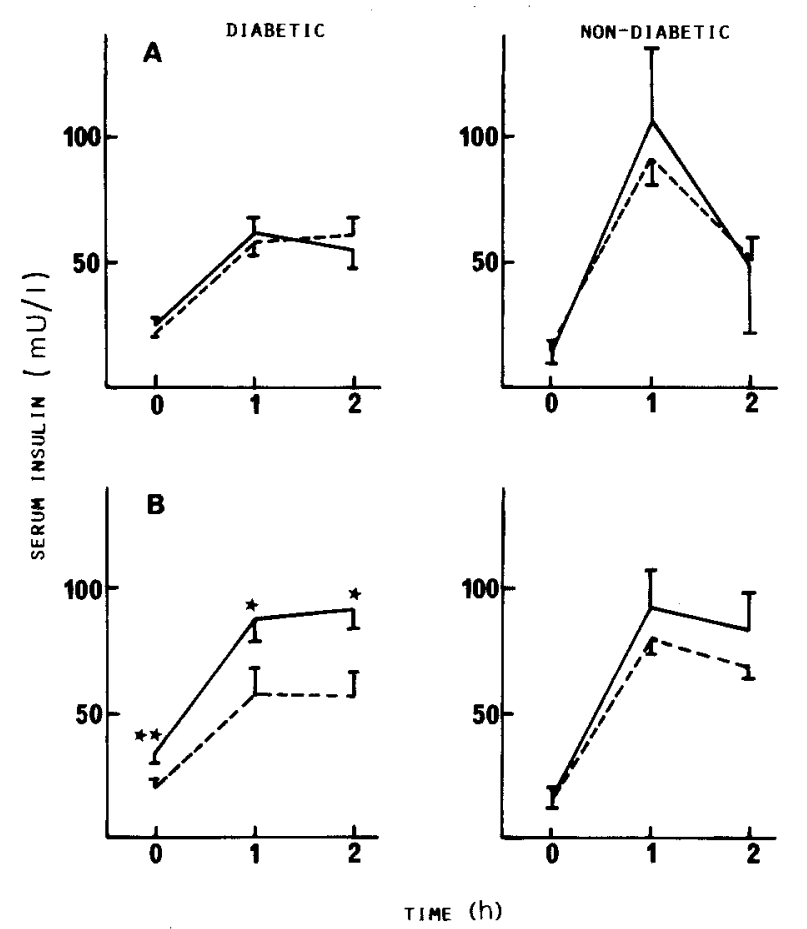

Fig. 2 A and B. Fasting and post-glucose serum insulin levels in relation to coronary heart disease by symptoms and ECG (CHD) in A men and B women. - subjects with $\mathrm{CHD}(n=23$ for diabetic men, 5 for non-diabetic men, 28 for diabetic women and 12 for nondiabetic women), - - subjects without CHD ( $n=47$ for diabetic men, 57 for non-diabetic men, 35 for diabetic women and 70 for nondiabetic women) ${ }^{*} p<0.05,{ }^{* *} p<0.01$ rum uric acid level than the female non-diabetic subjects, but no difference was found in men in this respect.

There were no significant differences in the history of smoking between the two groups. The prevalence of hypertension was significantly increased in both sexes of diabetic subjects (Table 1).

The prevalence of previous myocardial infarction was significantly higher in female diabetic than in female non-diabetic subjects $(p=0.007)$. Similarly, there was a trend towards a higher frequency of myocardial infarction in the male diabetic compared with the male non-diabetic subjects, but the difference was not statistically significant. The prevalence of coronary heart disease by symptoms and ECG was higher in both sexes of diabetic subjects than in the respective non-diabetic subjects $(p=0.001)$ (Table 1$)$. The detailed data concerning the prevalence of hypertension and various manifestations of CHD have been presented elsewhere [10].

Of the male diabetic subjects 35 were considered physically active during leisure time and 32 at work, respectively. The corresponding figures for male control subjects were 36 and 43 , for female diabetic subjects 24 and 31 and for female control subjects 46 and 36 .

\section{Cardiovascular risk factors in relation to coronary heart disease}

Myocardial infarction showed no significant associations with fasting or post-load blood glucose values either in diabetic or non-diabetic subjects, but a statistically significant association was found between coronary heart disease by symptoms and ECG and 1-h $(p=0.019)$ and 2-h $(p=0.032)$ post-load blood glucose values in female non-diabetic subjects (results not shown).

Myocardial infarction was not significantly related to fasting or post-glucose serum insulin levels in male diabetic and non-diabetic subjects. However, after adjustment for body mass index 1-h post-glucose serum insulin was significantly higher $(p=0.043)$ in male nondiabetic subjects with myocardial infarction than in those without (Fig.1). Fasting serum insulin level tended to be higher in female diabetic subjects with myocardial infarction than in those without $(p=0.056)$, and after adjustment for body mass index this difference became significant $(p=0.042)$. There were no significant differences in fasting and post-glucose serum insulin levels in female diabetic subjects with and without myocardial infarction, but after adjustment for body mass index 2 -h post-glucose serum insulin level was significantly higher in those with myocardial infarction $(p=0.027)$.

Fasting and post-glucose serum insulin values were consistently higher in female diabetic subjects with coronary heart disease by symptoms and ECG than in those without, and these differences persisted after ad- 

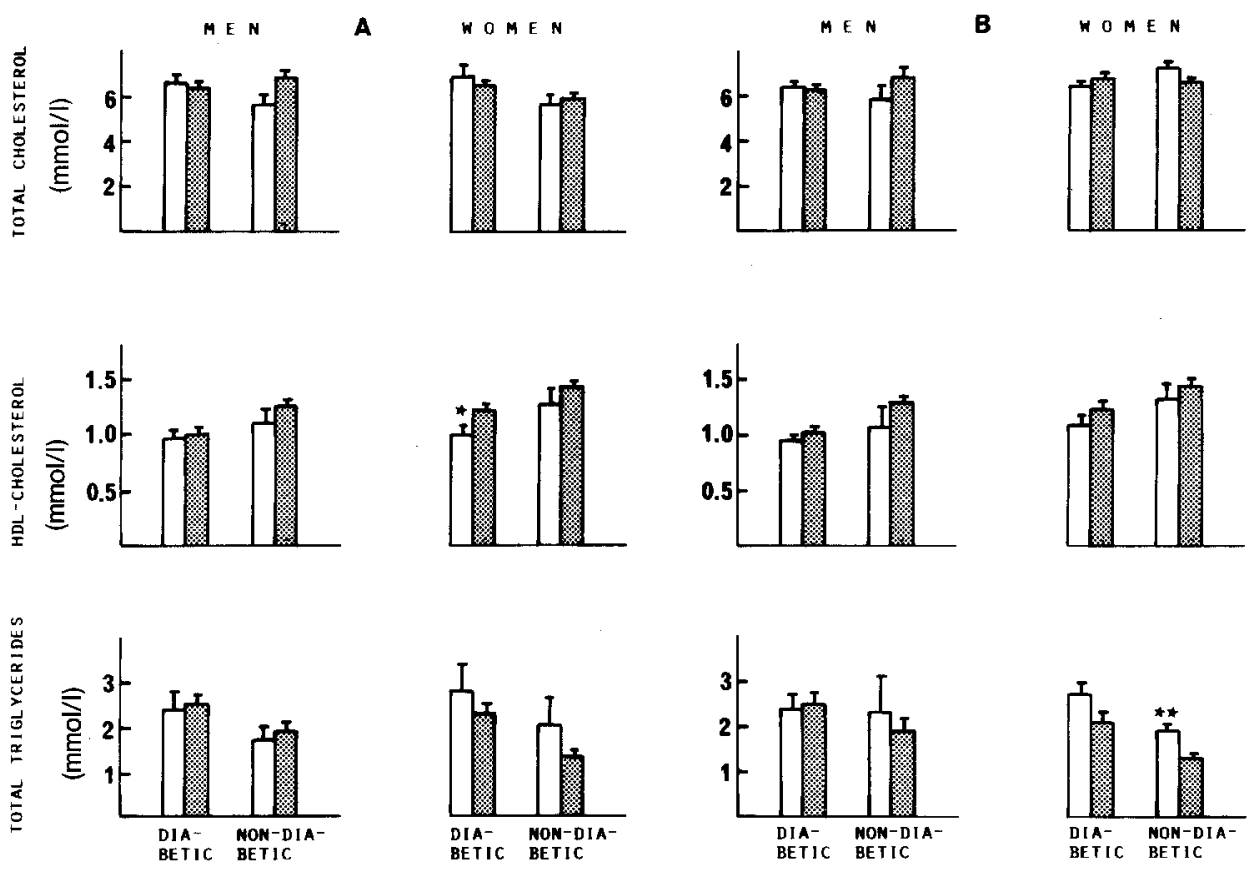

Fig. 3A and B. Serum lipids in relation to previous A myocardial infarction and B coronary heart disease by symptoms and ECG (CHD). $\square$ subjects with myo-
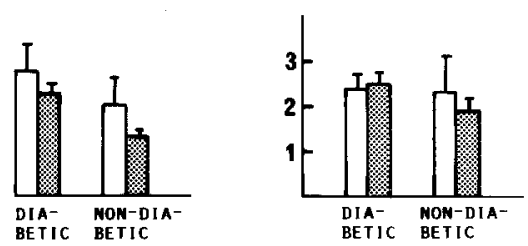
cardial infarction or $\mathrm{CHD}$, subjects without myocardial infarction or CHD ${ }^{*} p<0.05,{ }^{*} p<0.01$. Number of subjects in each group is given in Figures 1 and 2
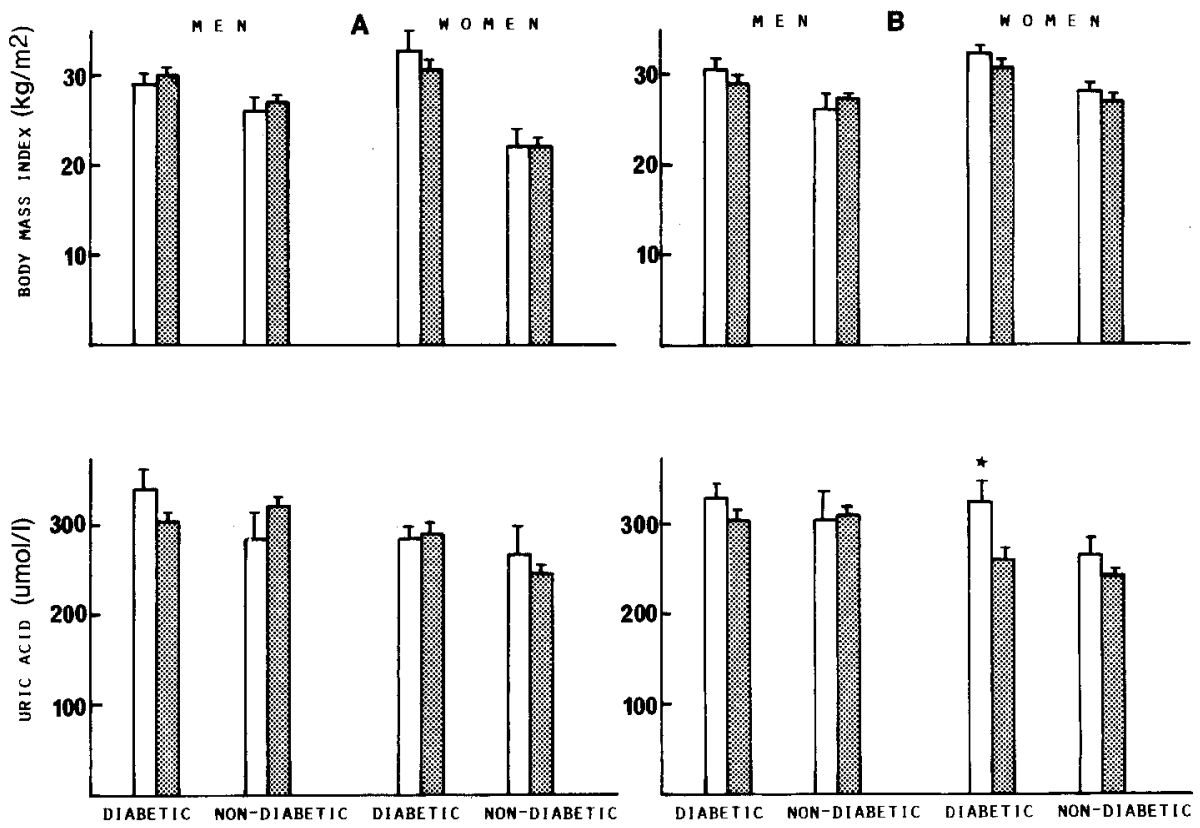

Fig.4. Body mass index and serum uric acid levels in relation to previous A myocardial infarction and $\mathbf{B}$ coronary heart disease by symptoms and ECG (CHD). $\square$ subjects with myocardial infarction or CHD, subjects without myocardial infarction or CHD. ${ }^{*} p<0.05$. Number of subjects in each group is given in Figures 1 and 2

justment for obesity but no significant associations were found in other groups (Fig. 2).

The relationship of myocardial infarction and coronary heart disease by symptoms and ECG to fasting and post-glucose serum insulin levels was also analysed in each group according to the level of physical activity during leisure time and at work. This analysis showed that the elevated serum insulin levels in subjects with myocardial infarction or coronary heart disease by symptoms and ECG were not attributable to physical inactivity.

The mean serum total cholesterol levels did not differ between subjects with and without myocardial in- farction either in diabetic or non-diabetic subjects. Female diabetic subjects with myocardial infarction had significantly lower HDL-cholesterol levels than those without $(p<0.05)$, but in other groups no significant differences were found in this respect. Serum total triglycerides were not related significantly to myocardial infarction in any groups. Neither serum total cholesterol nor HDL-cholesterol levels showed any significant association with coronary heart disease by symptoms and ECG in any groups, but serum triglycerides were higher in female non-diabetic subjects with coronary heart disease by symptoms and ECG than in those without $(p<0.01)$ (Fig.3). 
Table 2. Hypertension and smoking in relation to myocardial infarction and coronary heart disease by symptoms and ECG

\begin{tabular}{|c|c|c|c|c|}
\hline & \multicolumn{2}{|l|}{ Men } & \multicolumn{2}{|l|}{ Women } \\
\hline & $\begin{array}{l}\text { Diabetic } \\
\text { subjects }\end{array}$ & $\begin{array}{l}\text { Control } \\
\text { subjects }\end{array}$ & $\begin{array}{l}\text { Diabetic } \\
\text { subjects }\end{array}$ & $\begin{array}{l}\text { Control } \\
\text { subjects }\end{array}$ \\
\hline $\begin{array}{l}\text { Myocardial infarcti } \\
\text { Subjects with hy- }\end{array}$ & ${ }_{10 / 43(23)^{\mathrm{a}}}$ & $1 / 23$ & $9 / 44(20)$ & $4 / 34(12)^{d}$ \\
\hline $\begin{array}{l}\text { Subjects without } \\
\text { hypertension }\end{array}$ & $3 / 27(11)$ & $4 / 39(10)$ & $2 / 19(11)$ & $0 / 48 \quad(0)$ \\
\hline $\begin{array}{l}\text { Positive smoking } \\
\text { history }^{c}\end{array}$ & $11 / 57(19)$ & $3 / 41 \quad(7)$ & $2 / 8 \quad(25)$ & $1 / 5(20)$ \\
\hline $\begin{array}{l}\text { Negative smok- } \\
\text { ing history }\end{array}$ & $2 / 13(15)$ & $2 / 21(10)$ & $9 / 55(16)$ & $3 / 77$ \\
\hline \multicolumn{5}{|c|}{ Coronary heart disease by symptoms and ECG } \\
\hline $\begin{array}{l}\text { Subjects with hy- } \\
\text { pertension }\end{array}$ & $18 / 43(42)$ & $2 / 23$ & $21 / 44(48)$ & $9 / 34(26)^{d}$ \\
\hline $\begin{array}{l}\text { Subjects without } \\
\text { hypertension }\end{array}$ & $5 / 27(19)$ & $3 / 39(8)$ & $7 / 19(37)$ & $3 / 48 \quad(6)$ \\
\hline $\begin{array}{l}\text { Positive smoking } \\
\text { history }\end{array}$ & $21 / 58(36)$ & $4 / 41(10)$ & $5 / 8(63)$ & $2 / 5(40)$ \\
\hline $\begin{array}{l}\text { Negative smok- } \\
\text { ing history }\end{array}$ & $2 / 12(17)$ & $1 / 21$ & $23 / 55(42)$ & $10 / 77(13)$ \\
\hline
\end{tabular}

${ }^{a}$ Number of cases/total number of subjects and prevalence (\%). ${ }^{b}$ systolic blood pressure $\geqslant 160 \mathrm{mmHg}$ and/or diastolic blood pressure $\geqslant 95 \mathrm{mmHg}$ and $/$ or drug treatment for hypertension; " current and ex-smokers; ${ }^{d} p<0.05$ $\left(\chi^{2}\right.$-test $)$

Table 3. Cardiovascular risk factors in relation to coronary heart disease by symptoms and ECG. Multiple logistic analysis

\begin{tabular}{|c|c|c|c|}
\hline Parameter & $\begin{array}{l}\text { Regression } \\
\text { coefficient }\end{array}$ & $\begin{array}{l}\text { Standard } \\
\text { error }\end{array}$ & t-value \\
\hline \multicolumn{4}{|l|}{ Men } \\
\hline Hypertension ${ }^{d}$ & 0.9860 & 0.5139 & $1.92^{\mathrm{a}}$ \\
\hline Smokinge & 0.4604 & 0.6605 & 0.70 \\
\hline Age & 0.08764 & 0.0449 & $1.95^{\mathrm{a}}$ \\
\hline Total cholesterol & -0.1041 & 0.2218 & -0.47 \\
\hline Triglycerides $^{f}$ & -0.1866 & 1.3650 & -0.14 \\
\hline HDL-cholesterol & -1.4859 & 1.2915 & -1.15 \\
\hline Body mass index & 0.02638 & 0.0621 & 0.42 \\
\hline $2-\mathrm{h}$ insulin $^{\mathrm{f}}$ & -0.6479 & 0.7987 & -0.81 \\
\hline Diabetes & 1.1724 & 0.5864 & $2.0^{\mathrm{b}}$ \\
\hline \multicolumn{4}{|l|}{ Women } \\
\hline Hypertension ${ }^{d}$ & 0.5193 & 0.4946 & 1.05 \\
\hline Smokinge & 1.8439 & 0.8110 & $2.27^{\mathrm{b}}$ \\
\hline Age & 0.05830 & 0.04422 & 1.32 \\
\hline Total cholesterol & 0.1666 & 0.2323 & 0.50 \\
\hline Triglycerides ${ }^{f}$ & 1.7796 & 1.440 & 1.23 \\
\hline HDL-cholesterol & 0.3706 & 0.9098 & 0.40 \\
\hline Body mass index & 0.0301 & 0.0496 & 0.61 \\
\hline 2-h insulin ${ }^{f}$ & 2.0436 & 0.8314 & $2.46^{\mathrm{c}}$ \\
\hline Diabetes & 1.1707 & 0.5324 & $2.20^{\mathrm{b}}$ \\
\hline
\end{tabular}

a $0.10>p>0.05 ;$ b $p<0.05 ;{ }^{c} p<0.01$; ${ }^{\mathrm{d}}$ systolic blood pressure $\geq 160 \mathrm{mmHg}$ and/or diastolic blood pressure $\geqslant 95 \mathrm{mmHg}$ and/ or drug treatment for hypertension; e current and ex-smokers;

${ }^{f}$ logarithmic transformation before analysis

Body mass index was not related to the occurrence of myocardial infarction or coronary heart disease by symptoms and ECG either in diabetic or non-diabetic subjects. Serum uric acid levels showed no association with myocardial infarction, but it was higher in female diabetic subjects with coronary heart disease by symptoms and ECG $(325 \pm 19 \mu \mathrm{mol} / \mathrm{l})$ than in those without $(261 \pm 15 \mu \mathrm{mol} / 1 ; p=0.016)$. In other groups such an association was not found (Fig. 4).
The prevalence of myocardial infarction was approximately two fold in male and female diabetic subjects with hypertension than in those without, but the differences were not significant. In male diabetic subjects, hypertension tended to associate also with coronary heart disease by symptoms and ECG. In female non-diabetic subjects, both myocardial infarction and coronary heart disease by symptoms and ECG associated with the presence of hypertension (Table 2).

Smoking did not show any significant relationship to either the occurrence of myocardial infarction or coronary heart disease by symptoms and ECG. However, in all groups the prevalence of coronary heart disease tended to be higher in those subjects with a positive smoking history than in those who had never smoked (Table 2).

Multiple logistic analyses were carried out separately for men and women, combining diabetic and non-diabetic subjects, in order to find out the independent effect of diabetes from other cardiovascular risk factors on the occurrence of coronary heart disease. In addition to diabetes which showed a significant association in both sexes $(p<0.05)$, hypertension and age showed a borderline association with coronary heart disease by symptoms and ECG in men, whereas in women, besides diabetes, smoking $(p<0.05)$ and the high 2-h post-glucose serum insulin $(p<0.01)$ related significantly to coronary heart disease (Table 3 ). Multiple logistic analyses were carried out also in male and female diabetic subjects to examine which of the cardiovascular risk factors among diabetic subjects would show a relationship to coronary heart disease. In men, only hypertension showed an independent, significant association $(\mathrm{t}=2.27 ; p<0.05)$ to coronary heart disease, while high 2 -h post-glucose serum insulin level did so in women $(t=2.33 ; p<0.05)$.

\section{Discussion}

In the present series of newly diagnosed Type 2 diabetic subjects, serum total cholesterol was not related to the presence of CHD. On the contrary, in some prospective studies, a high serum cholesterol level has been shown to increase the risk of CHD in diabetic subjects to the same extent as in non-diabetic subjects [18, 19], even though a less consistent association among diabetic subjects has also been found [9]. The absence of an association in the present study may be due to the cross-sectional study design which has its limitations in the identification of risk factors.

Diabetic subjects had lower HDL-cholesterol levels than non-diabetic subjects. Furthermore, low HDLcholesterol was associated with myocardial infarction in female diabetic subjects, but in multiple logistic analyses this association was not significant. In a study carried out on the Framingham cohort, low HDL-cholesterol was related to the incidence of coronary heart dis- 
ease in diabetic subjects [20], and in some cross-sectional studies, low HDL-cholesterol has been associated with a vascular disease [21] or previous myocardial infarction [22] in middle-aged diabetic subjects. Thus, low HDL-cholesterol might be one factor involved in the increased risk of CHD among Type 2 diabetic patients.

Among various cardiovascular risk factors, hypertension has invariably shown a contribution to CHD morbidity and mortality in prospective studies on middle-aged diabetic patients. The relative impact of hypertension on the risk of CHD has been found to be similar or even higher, in diabetic than non-diabetic subjects [9, $18,23,24]$. In the present study, the prevalence of hypertension was higher in diabetic than in non-diabetic subjects, and diabetic subjects with hypertension showed a twofold frequency of myocardial infarction than those without. Furthermore, in diabetic men hypertension showed an independent relationship to CHD by symptoms and ECG. The cross-sectional study design might weaken the association between hypertension and CHD in female diabetic subjects. Nevertheless, the present results are, by and large, in accordance with those of prospective studies, and they suggest that hypertension might be one of the factors responsible for excessive CHD among patients with Type 2 diabetes.

Diabetic patients did not differ from non-diabetic subjects with respect to the history of smoking. In univariate analyses, the association of smoking with CHD by symptoms and ECG was not significant, but its contribution in multiple logistic analysis became significant in women. There is, however, no indication to suggest that smoking might increase the risk of CHD in diabetic subjects more than in non-diabetic subjects [18]. In fact, in some studies, diabetic subjects have shown less consistent association between smoking and CHD than non-diabetic subjects $[9,19]$.

In the present study, diabetic subjects were more obese than non-diabetic subjects, but obesity itself showed no consistent association with $\mathrm{CHD}$, in agreement with prospective studies $[9,18]$.

There was some association between high serum uric acid and CHD in female diabetic subjects. However, this finding is strongly confounded by frequent use of diuretics in subjects with CHD [10].

In the present study, high fasting serum insulin tended to be associated with myocardial infarction in female diabetic subjects, as did high post-glucose serum insulin levels in female non-diabetic subjects. In addition, there was a consistent association between high serum insulin and CHD by symptoms and ECG in female diabetic subjects. Multiple logistic analysis showed that the relationship between high $2-h$ post-glucose serum insulin levels and CHD was independent of other cardiovascular risk factors, including HDL-cholesterol and obesity. Neither could physical inactivity explain the higher serum insulin levels in subjects with CHD. In three prospective population studies, an association between high serum insulin and the risk of CHD has been found in non-diabetic men [7, 25, 26], but not in nondiabetic women [25]. Two previous cross-sectional studies carried out in maturity-onset diabetic patients have indicated that high serum insulin might be related to atherosclerotic vascular disease $[27,28]$. Moreover, a recent prospective study showed that hyperinsulinaemia was associated with the development of ECG abnormalities in Type 2 diabetes [29]. Thus, our results, in conjunction with experimental studies [30] and previous clinical and epidemiological findings, suggest that high serum insulin might contribute to excessive CHD in Type 2 diabetic patients, in whom serum insulin may be unphysiologically high, particularly before the clinical onset of diabetes $[31,32]$. The association between high serum insulin level and CHD was confined to female diabetic subjects, which could be of importance with respect to the marked increase in relative risk of CHD among female diabetic patients [18, 23]. However, in some studies, low rather than high serum insulin has shown some association with the risk of CHD [8], but reasons for such contradictory findings are unknown.

Several studies indicate that the excessive occurrence of CHD among diabetic patients cannot be explained by cardiovascular risk factors alone $[9,18,23]$. In the present study, the independent association between diabetes and CHD became significant in both sexes, even after allowing for the effects of various risk factors including HDL-cholesterol and serum insulin.

In conclusion, cardiovascular risk factors did not account solely for increased prevalence of CHD in newly diagnosed Type 2 diabetes. Among the various risk factors examined, hypertension showed the most consistent association to CHD in diabetic men and high serum insulin levels in diabetic women.

Acknowledgements. This work was supported by grants from the Medical Research Council of the Academy of Finland.

\section{References}

1. Jarrett RJ, Keen H, Chakrabarti R (1982) Diabetes, hyperglycaemia and arterial disease. In Keen H, Jarrett RJ (eds) Complications of diabetes, 2nd edn. Edward Arnold, London, pp 179-204

2. Pyörälä K, Laakso M (1983) Macrovascular disease in diabetes mellitus. In: Mann JI, Pyörälä K, Teuscher A (eds) Diabetes in epidemiological perspectives. Churchill Livingstone, Edinburgh, pp 183-247

3. Jarrett RJ, Keen H, Fuller JH, McCartney M (1979) Worsening to diabetes in men with impaired glucose tolerance (borderline diabetes). Diabetologia 16:25-30

4. Keen H, Jarrett RJ, McCartney P (1982) The ten-year follow-up of the Bedford study (1962-1972): glucose tolerance and diabetes. Diabetologia 22: 73-78

5. Stamler R, Stamler J (eds) (1979) Asymptomatic hyperglycemia and coronary heart disease. A series of papers by the international collaborative group based on studies in fifteen populations. $\mathbf{J}$ Chron Dis 32:638-873

6. Fuller JH, Shipley MJ, Rose G, Jarrett RJ, Keen H (1980) Coronary-heart-disease risk and impaired glucose tolerance. The Whitehall study. Lancet 1: 1373-1376

7. Pyörälä K (1979) Relationship of glucose tolerance and plasma in- 
sulin to the coronary heart disease: results from two population studies in Finland. Diabetes Care 2: 131-141

8. Jarrett RJ, McCartney P, Keen H (1982) The Bedford survey: ten year mortality rates in newly diagnosed diabetics, borderline diabetics and normoglycaemic controls and risk indices for coronary heart disease in borderline diabetics. Diabetologia 22: 79-84

9. Fuller JH, Shipley MJ, Rose G, Jarrett RJ, Keen H (1983) Mortality from coronary heart disease and stroke in relation to degree of glycaemia: the Whitehall study. Br Med J 2: 867-870

10. Uusitupa M, Siitonen O, Aro A, Pyörälä K (1985) Prevalence of coronary heart disease, left ventricular failure and hypertension in middle-aged, newly diagnosed Type 2 (non-insulin-dependent) diabetic subjects. Diabetologia 28: 22-27

11. WHO Expert Committee on Diabetes Mellitus (1980), WHO, Second report, No. 646 , Geneva

12. Rose GA (1962) The diagnosis of ischaemic heart pain and intermittent claudication in field surveys. Bull WHO 27: 645-658

13. Rose GA, Blackburn H (1968) Cardiovascular survey methods. WHO Monograph Series 56, Geneva

14. Penttilä IM, Voutilainen E, Laitinen P, Juutilainen P (1981) Comparison of different analytical and precipitation methods for the direct estimation of serum high-density lipoprotein cholesterol. Scand J Chem Lab Invest 41: 353-360

15. Rösclau P, Bernt E, Gruber W (1974) Enzymatische Bestimmung des Gesamtcholesterins im Serum. Z Klin Chem Biochem 12: 403-407

16. Wahlefeld AW (1974) Triglycerides. Determination after enzymatic hydrolysis. In: Bergmeyer HU (ed) Methods in enzymatic analysis. Academic Press, New York, pp 1831-1835

17. Armitage P (1980) Statistical methods in medical research. 1st ed. Blackwell, Oxford, pp 384-388

18. Kannel WB, McGee DL (1979) Diabetes and cardiovascular risk factors: the Framingham Study. Circulation 69: 8-13

19. Reunanen A, Laakso M, Pyörälä K (1983) Cardiovascular and coronary heart disease mortality of diabetics and non-diabetics; impact of risk factors. Am Coll Cardiol 2: 600 (Abstract)

20. Gordon T, Castelli WP, Hjortland MC, Kannel WB, Dawber TR (1977) Diabetes, blood lipids, and the role of obesity in coronary heart disease risk in women. Ann Int Med 87:393-397

21. Reckless JPD, Betteridge DJ, Wu P, Bayne B, Galton DJ (1978) High-density and low-density lipoproteins and the prevalence of vascular disease in diabetes mellitus. Br Med J 1: 883-886

22. Laakso M, Voutilainen E, Pyörälä K, Sarlund H (1984) Associa- tion of low serum HDL-cholesterol and $\mathrm{HDL}_{2}$-cholesterol with coronary heart disease in non-insulin-dependent diabetes. Diabetologia 27: $301 \mathrm{~A}$

23. Heyden S, Heiss G, Bartel AG, Hames CG (1980) Sex differences in coronary mortality among diabetics in Evans county, Georgia. J Chronic Dis 33:265-273

24. Aromaa A, Reunanen A, Pyörälä K (in press) Hypertension and mortality in diabetic and non-diabetic Finnish men. J Hypertension

25. Welborn TA, Wearne K (1979) Coronary heart disease incidence and cardiovascular mortality in Busselton with reference to glucose and insulin concentrations. Diabetes Care 2: 154-160

26. Ducimetiere P, Eschwege E, Papoz J, Richard JL, Claude JR, Rosselin $G$ (1980) Relationship of plasma insulin levels to the incidence of myocardial infarction and coronary heart disease mortality in a middle-aged population. Diabetologia 19: 205-210

27. Kashyap ML, Magill F, Rojas L, Hoffman MM (1970) Insulin and non-esterified fatty acid metabolism in asymptomatic diabetics and atherosclerotic subjects. Can Med Assoc J 102: 1165-1169

28. Santen RJ, Willis PW, Fajans SS (1972) Atherosclerosis in diabetes mellitus. Correlations with serum lipid levels, adiposity and serum insulin level. Arch Int Med 130: 833-843

29. Hillson RM, Hockaday TDR, Mann JI, Newton DJ (1984) Hyperinsulinaemia is associated with development of electrocardiographic abnormalities in diabetics. Diabetes Res 1: 143-149

30. Stout RW (1981) The role of insulin in atherosclerosis in diabetics and non-diabetics. Diabetes 30 (Suppl 2): 54-57

31. Chiles R, Tzagournis M (1970) Excessive serum insulin response to oral glucose in obesity and mild diabetes. Diabetes 19: 458-464

32. Reaven GM (1979) Insulin resistance and insulin secretion in patients with chemical diabetes: implications concerning the pathogenesis of idiopathic diabetes mellitus. In: Camerini-Davalos RA, Hanover B (eds) Treatment of early diabetes. Plenum Press, New York, pp 187-200

Received: 2 January 1985

and in revised form: 27 June 1985

Dr. M: Uusitupa

Department of Medicine

Kuopio University Central Hospital

SF-70210 Kuopio

Finland 